UNIVERSITY OF WAIKATO

Hamilton

New Zealand

\title{
Lost in Transition? \\ Declining Returns to Education in Vietnam
}

Tinh Doan, Tran Quang Tuyen and Le Quan

\section{Department of Economics \\ Working Paper in Economics 01/16}

March 2016

\section{Corresponding Author}

\section{Tinh Doan}

Economics Department

University of Waikato

Hamilton

NEW ZEALAND, 3240

and

University of Economics and Business, VNU

Hanoi, VIETNAM

Email: tinhdoan@waikato.ac.nz

\section{Tran Quang Tuyen}

University of Economics and Business, VNU

Hanoi, VIETNAM

Email: tuyentran@uvn.edu.vn

\section{Le Quan}

University of Economics and Business, VNU

Hanoi, VIETNAM

Email: lequan@edu.vn 


\begin{abstract}
There is evidence of a rapid increase in the returns to education in Vietnam in the 1990s and 2000s. There was a substantial change in education policy in the 2000 s, especially opening up education opportunities for education providers to expand educational facilities and training. These changes could lead to a decline in the returns to education. To provide up-to-date estimates of the returns, we re-visit the returns using updated large-scale survey data to 2014 . We apply the Heckman selection estimators to correct for selection bias and find that the return to education in Vietnam increased quickly up to the global financial crisis in 2008/2009 and declined sharply thereafter. This raises at least two questions: is the highereducated labour force oversupplied or is there a large distortion in the labour market?
\end{abstract}

\title{
JEL Classification
}

C52, I26, J21, J31

\section{Keywords}

economic transformation

returns to education

education supply

wage setting

Vietnam 


\section{Introduction}

Higher return to schooling is an incentive for investment in education (Psacharopoulos and Patrinos 2004). Increasingly, governments and other agencies have used returns to education to guide macro-policy decisions about funding education and education reforms (OECD 2003). Returns to education are a useful indicator of the productivity of education and an incentive for investing in education and human capital formation. The lowering of returns to education has some important implications, such as increasing the supply of educated labour or distortions in the labour market and/or mismatching in the labour market and out-dated skills in training. These outcomes may send a negative signal to investment in human capital formation especially higher education.

A common trend regarding transition economies is that the returns to schooling tend to rise as economic reform progresses especially in early economic transition (Orazem and Vodopivec 1995, Fleisher, Sabirianova and Wang 2005, Munich, Svejnar and Terrell 2005, Flabbi, Paternostro and Tiongson 2008, ${ }^{1}$ Colclough, Kingdon and Patrinos 2010, Doan and Gibson 2012, Večerník 2013). The trend marks the movement away from distorted labour markets and the effects of longer-term changes in patterns of human capital formation.

There is a consensus that in the early stage of transition, the returns to education increase as well as wage inequality. The argument is that market liberalization and competition leads to increasing returns to education where education is valued more effectively. There is a link between returns to education and the speed of economic reform and the size of the state sector (Yang 2004, Fleisher, Sabirianova and Wang 2005). Returns are determined by the interaction between supply factors, such as relative supply of skilled workers, and demand factors, such as skill requirements due to technology change (Katz and Autor 1999, Heckman, Loch and Todd 2003).

In advanced industrial countries, or well-functioning markets, the returns to education or human capital and physical capital tend to be equated at the margin (Psacharopoulos and Patrinos 2004). Psacharopoulos (1994) and Psacharopoulos and Patrinos (2004) report an average return to education of about $10 \%$ for the world and $9.6 \%$ for Asia. For low and middle income countries, the return is higher at between $11.2 \%$ and $11.7 \%$ per additional year of schooling.

In contrast, education can be undervalued in a centrally planned economy (Campos and Jolliffe 2003). In transition economies, the returns to education have increased rapidly during market liberalisation. Fleisher et al. (2005) proposed two explanations: the first argues that

1 The weak evidence of quick rising returns in eight European transition economies was due to the 'richer' model specification where they included many variables such as urban, being married, occupation, sector, trade union, ... this leads to stealing part of education coefficient (see Pscharalopous and Patrinos 2004). Their 'basic' and 'basic balanced' specifications do show a clear rising trend of returns to education. 
economic reforms allow an easing of the legal, regulatory, and institutional constraints on wage-setting and allow workers to move across regions, industries and employers more easily. Thus, the faster the reform, the more quickly the returns to education adjust to market rates. The other hypothesis proposes that structural transformations, disruptions and economic disequilibrium make highly educated individuals able to respond to and benefit from better job opportunities.

The fast rise of returns to education during transitions parallels abrupt changes in the political and economic system of post-communist countries. Highly-skilled workers were valued, not because their productivity would have miraculously risen quickly, but because the value system of the society had changed. Wages were now determined by a freer market and education was valued more than previously (Mysíková and Večerník 2014). But after a period of economic transformation, the trend of returns to education in transition economies seems to have reversed particularly after the global financial crisis (GFC). The returns had increased in early the early stages of transition, but then declined slightly from the GFC. The declining return has been attributed to the increasing share of tertiary educated workers in the working age population (see, for example, Mysíková and Večerník 2014).

In well-functioning economies, changes to returns to education can be due to changes in skilled labour supply and demand. Higher returns to education means that workers are better paid for higher productivity (Becker 1975, and Mincer 1974). Becker (1975) states that marginal returns to higher education fall when the proportion of the population with higher education rises. Educational expansion is usually followed by a decline in returns to education (Psacharopoulos 1989). The evidence seems to be more consistent with the human capital theory of the relationship between education and earnings. However, the returns would remain stable if the extra supply of higher educated workers is offset by the similar additional demand for higher skilled workers.

Using data from Eastern and Western European countries from 2004 to 2011, Mysíková and Večerník (2014) show a significantly negative relationship between the share of tertiary education and the returns to education in Western countries but no strong effect in Eastern European countries. They argue that along with economic liberalization, higher education has expanded in Easter European economies. However, the increase in higher skilled labour supply in Easter European economies did not exceed the increased market demand for skilled labour. The study also found that 2009 appears to be a break-point when rising returns to education started to decline.

Some studies suggest that education returns in Vietnam followed the typical pattern of fast rising returns especially in 2000s (see, for example, Doan and Gibson 2012). Comparing the world and Asian rate of returns at about 10\% (Psacharopoulos 1994, Psacharopoulos and Patrinos 2004), the rate of returns for Vietnam is well in line with Asia. It is likely that the economic reforms in Vietnam would have had a sufficient impact on the labour market. 
Economic reform and economic growth in Vietnam has slowed down particularly after the GFC. The desire to control the economy has again led the Communist Party not to pursue more economic freedom for the private sector. After two decades of growth, the economy started to lose its growth momentum from the late 2000s. Instead of more decentralization and privatization, the government, which was controlled solely by the Communist party, has pursued the state-conglomerate model. The state-run conglomerate model appears to have serious problems from mismanagement, poor efficiency and corruption to crony capitalism. ${ }^{2}$ The economy has experienced a period of high inflation, serious budget deficits, declining foreign reserves, mismanaged fiscal and monetary policies, high unemployment and sluggish economic growth. Currently, the state sector still dominates economic activities, for example, $70 \%$ of total physical capital investment, $60 \%$ commercial loan value from banks and $70 \%$ of ODA, but just about $10 \%$ of employment. The severe distortion in the economy has impeded markets including the labour market.

Given a heavily distorted economy and labour market in Vietnam, higher-educated workers tend to work the in state sector (Coxhead and Phan 2013), while the transition in Eastern European economies resulted in the movement of skilled workers to the private sector to seek more productive or better paid jobs (Munich, Svejnar and Terrell 2005). The distortion in the Vietnamese labour market has occurred partly because the government wants to control key economic decisions as they concerned about losing socialism ideology if economic influence is shifted to non-state sectors.

There exists a high degree of economic policy distortion with heavily biased towards flavouring SOEs in Vietnam (IMF 2012). This has led to a generation of privileges for public servants and well-connected people. This situation has affected firm and workers behaviour in the labour market. Many workers therefore want to work in the public sector or SOEs to enjoy the privileges. Firms and local government entities want to recruit well-connected (with senior government officers) workers to take advantages of the relationship to exploit the privileges. Coxhead and Phan (2013) use the terms 'princelings' to describe this problem. In this situation, education is likely to be undervalued. It has recently become a phenomenon that in order to get promoted and earn a higher income, the most important factor is to have relationship with senior government officers, the second is to have family relatives or descendants of public officers (princelings), the third is to invest money in the forms of bribes and the least important requirement is to have knowledge (education).

The connections based on family ties have become an important factor determining the likelihood of gaining employment in the public sector in Vietnam (Oxhead and Phan 2013). The income premium of working in the state sector is higher than in the private sector. This situation discourages education investment for those who do not have the relationships or who are not descendants. Instead of investing more in education, families have turned to

2 https://www.stratfor.com/the-hub/vietnams-political-economy-transition-1986-2016 
'buying' jobs - that is, paying bribes - for their children to work in the state sector. That is, they choose to opt out of investment in education. Corruption has thus become very severe in Vietnam. Job buyers will try to gain returns from their 'job investment' by asking for and/or receiving bribes. Recent reports from the World Transparency Index show very little improvement in the corruption ranking of Vietnam over the last five years. Vietnam has been recently still ranked very low amongst East and Southeast Asian countries. A majority of workers in Vietnam have a low likelihood of finding employment in industries/occupation where returns to higher-quality education would justify the cost of their qualifications (Oxhead and Phan 2013).

If there does not exist a functioning labour market, some children will opt out of education to join the lower-skilled labour force and work in factories in industrial parks, exporting zones or special economic zones. Many higher educated graduates worked in offices with lower pay than those with lower qualifications working in manufacturing assembly factories. The declining returns to education will thus discourage education investment and harm human capital formation leading to a slower economic growth (Booth 2003). This is a significant risk for economic growth as growth in the long run relies on productivity (Krugman 1992).

Apart from labour market distortion, the increasing supply of higher education may affect the returns to education. There is a boom in education supply, especially higher education, in transition economies. Under a command economy, education uptake, particularly higher education, is subject to a quota set by the central government which was often well below demand. Due to an open policy on education, new opportunities have resulted in a mushrooming of education providers, including tertiary education. As a result, student numbers surged. Soon enough, the labour market was faced with an increasing number of people with higher diplomas. Although some transition countries are still faced with a shortage of skilled workers (Rutkowski 2007), the increase in rewards for highly educated people cannot be endless and should then slow down, stay flat, or decline eventually.

In Vietnam, a significant increase in intakes into tertiary education has been observed in the middle and third part of 2000s (see Figure 1). The gross enrolment rate in tertiary education increased from around $10 \%$ for many years prior to 2003 to $15.9 \%$ in 2005 . The enrolment rate then increased again from $15.9 \%$ in 2005 to $24.4 \%$ in 2011 . Between 2003 and 2011, the gross tertiary enrolment rose by a remarkable $144 \%$. The increase in uptake beginning in 2004 would start having an effect from 2008 onwards as the additional students graduated after three or four years of training. The effect in the following years would be stronger as incremental numbers of students graduate.

The quality of the training is not always followed with quantity improvements (Christian 2014). Economic growth has been sluggish since the GFC and the Vietnam economy has not been able to absorb the extra graduates. Data from Ministry of labour, Invalids and Social 
Affairs reveals that except for non-educated people (who have the highest unemployment rate $)^{3}$, people with university degrees have a higher unemployment rate than any other group. This is unusual, and implies an oversupply of the higher education graduates and possibly a lower quality of the tertiary education training.

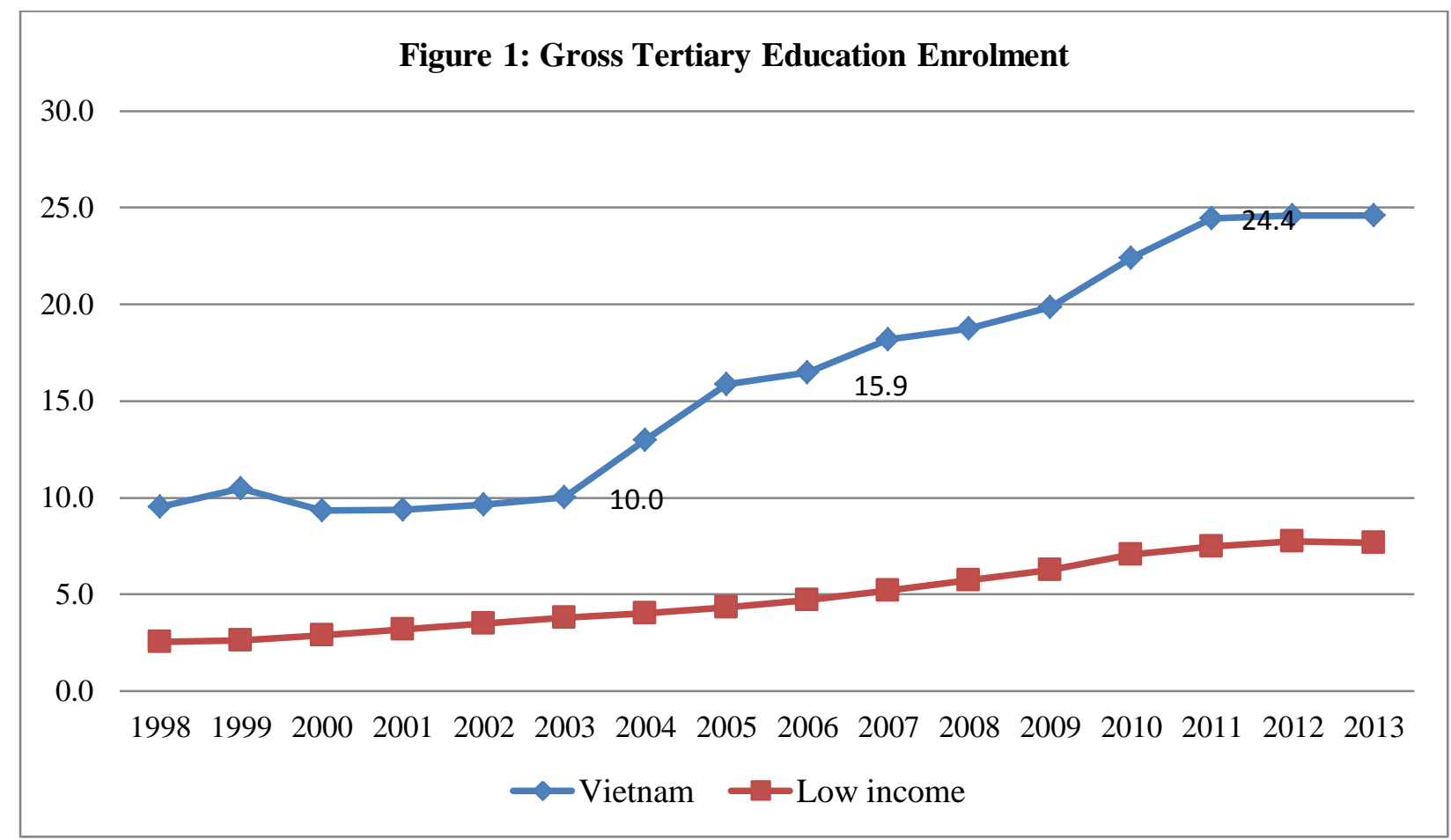

Source: World Development Indicators, http://data.worldbank.org/indicator/SE.TER.ENRR/countries/VN-4E$\underline{\mathrm{XN}}$ display=default

The qualifications of higher educated workers are not at the quality level required. Christian (2014) shows unbalanced training in Vietnam education where education has focused mainly on scale expansion, but the quality of education has been questionable. There is a need to focus on both quantity and quality of education. In short, it is important to provide the appropriate skills to meet Vietnam's continued economic modernization. Apart from job-specific skills, Vietnamese employers value cognitive skills, such as problem solving and critical thinking, and behavioural skills, such as team work and communication. In 'Skilling up Vietnam', Christian (2014) proposes a three-step holistic skills strategy. Vietnam's skills development efforts should focus on promoting school readiness through early childhood development, ensuring a strong cognitive and behavioural foundation in general education and building job-relevant technical skills through a more connected system among employers, students and universities, and vocational schools.

In summary, an oversupply of educated workers, lower demand for educated workers due to slowing economic growth, distortion in the labour market and the quality of training may be some key factors driving the fall of the returns to education. This paper aims at

3 http://www.molisa.gov.vn/Images/FileAnPham/fileanpham20151227165350.pdf 
provide an up-to-date estimate for returns to education in Vietnam. This task is important for at least two reasons. First, it provides information on the dynamics of the labour market in Vietnam during different stages of its economic transformation. Secondly, it provides implications for adjustments in education investment and education policy. Section 2 presents the data and econometric specifications. Section 3 presents the results. Discussion of possible explanations for the changing returns and our conclusions are presented in Section 4.

\section{Data and Model Specification}

\subsection{Data}

Data used in this paper are from the 1998, 2002, 2004, 2006, 2008, 2010, 2012 and 2014 rounds of the Vietnam Household Living Standards Survey (VHLSS) conducted by the General Statistics Office of Vietnam (GSO). The data consist of around 6,000 households in 1998 to about 9,400 households in 2014 except for the VHLSS2002 round which has about 30,000 households. ${ }^{4}$ The surveys offer a large number of household members from 28,624 household members in VHLSS1998 to about 40,000 households in 2014 (except a large number in VHLSS2002 with more than 132,000 members). Sub-samples of wage-earners aged from 15 to 60 are used in the estimations, which yield 3,244 from VHLSS1998, 26,268 from VHLSS2002, 7,177 from VHLSS2004, 7,436 from VHLSS2006, 7,532 from VHLSS2008, 7,166 from VHLSS2010, 7,758 from VHLSS2012, and 7,868 from VHLSS2014. A consistent method of randomly stratified sampling across rounds of the survey enables us to compare the results over time. These samples are representative for the national population of Vietnam.

We use the average hourly income from the first and second job (if a worker has two jobs). General, higher education and vocational training were used to calculate years of schooling. The individual's highest education was used. For example, if a person has a high school diploma (12 years) and a three-year college diploma (12 plus 3 years), this person's years of schooling should be 15 .

\subsection{Estimation Methods}

To estimate the returns to schooling, we start with the Mincerian earnings equation:

$$
\operatorname{LnY} Y_{i}=\alpha+\beta_{1} S_{i}+\beta_{2} \operatorname{Exp}_{i}+\beta_{3} \operatorname{Exp}_{i}^{2}+\varepsilon_{\mathrm{i}}
$$

where $\operatorname{Ln} Y$ is the natural logarithm of hourly wages including bonuses, allowances and subsidies (both in cash and in-kind), $S$ is years of schooling, Exp is potential experience (calculated as age minus schooling years minus six) and the experience squared term, $\operatorname{Exp}^{2}$, is

4 VHLSS2002 dataset has significantly more observations than other VHLSS datasets. It was due to the GSO taking over the sample design from the World Bank in 2002 and wanting statistically significant results at the province level. Survey administration problems and costs caused the GSO to scale back its ambitions afterwards and maintained the sample sizes at around 9,000 households. 
included to allow a non-linear pattern in lifecycle earnings. Unlike other papers, we use the simple form of Mincerian earnings equation which includes only education, experience, experience squared and gender to estimate the returns because inclusion of other variables, such as occupation and sector, will rob some parts of the effect of education on earnings (Psacharapolous and Patrinos 2004).

To test the trend of return to schooling over time, we add an interaction term between years of schooling and a year dummy for the compared year (year2). In addition, to capture the gender difference in earnings, we also include a dummy variable for gender and its interaction term with the compared year dummy. The stand-alone year dummy captures the time effects, including inflation, as we use nominal income in this study. The interactions between year dummy and the explanatory variables capture changes in the impact of each explanatory variable in earnings across years. The estimation model is now:

$$
\begin{aligned}
& \operatorname{LnY}_{i}=\alpha+\delta_{0} . \text { Year }_{2}+\beta_{1} . S_{i}+\delta_{1} . S_{i} * \operatorname{Year}_{2}+\beta_{2} . \operatorname{Exp}_{i}+\delta_{2} . \operatorname{Exp}_{i} * \operatorname{Year}_{2}+\beta_{3} \cdot \operatorname{Exp}_{i}^{2} \\
& +\delta_{3} . \operatorname{Exp}_{i}^{2} * \text { Year }_{2}+\beta_{4} \text {.Gender }+\delta_{4} \text {. Gender } * \text { Year }_{2}+v_{i}
\end{aligned}
$$

The estimates may be biased due to sample selection when the subset of wage earners used for the Mincerian earnings equation is not randomly sampled from the general population. The ordinary least squares (OLS) estimates using the Mincerian earnings equation may be biased and not representative for the whole population since the OLS estimates the return to schooling for a subset of wage-earners only. To address the problem we apply the sample selection model (Heckman 1979) as follows:

Wage Equation:

$$
w_{i}=z_{i} \beta_{l}+u_{1 i}
$$

where $w_{i}$ is log of hourly wage, $z_{i}$ is a vector of schooling, experience and gender variables for individual $i$.

Selection Equation:

$$
h_{i}^{*}=x_{i} \beta_{2}+u_{2 i}
$$

where $h_{i} *$ is a latent variable and $w_{i}$ is observed if $h_{i}^{*}>0$, and $w_{i}$ is not observed if $h_{i}^{*} \leq 0 . X_{i}$ is a vector of schooling, experience, gender, household size and household non-wage income. The $\beta_{1}$ and $\beta_{2}$ are vectors of coefficients. The selection equation is used to correct the sample selectivity bias. People may self-select into the wage employment sector according to their education, household size and non-wage income. Furthermore, the assumptions about the errors are that:

$$
u_{1 i} \sim N I D\left(0, \sigma^{2}\right) \text { and } u_{2 i} \sim N(0,1) \text { and } \quad \operatorname{cov}\left(u_{1 i}, u_{2 i}\right)=\rho_{12}
$$

In the first estimation stage, a binary probit model on all observations (those in wage employment and those not) is used to estimate the correction term $\lambda_{i}$, which is the inverse Mill's ratio or Heckman's lambda: $\lambda_{i}=\phi\left(x_{i} \beta_{2}\right) / \Phi\left(x_{i} \beta_{2}\right)$ where $\phi$ is a normal probability distribution function and $\Phi$ is a normal cumulative distribution function $(c d f)$. The term is then included in the second stage of the augmented earnings function: 


$$
w_{i}=z_{i} \beta_{1}+\sigma_{12} \cdot \lambda_{i}+\eta_{i}
$$

These two equations can also be estimated in one single step procedure using the Heckman maximum likelihood estimator, which is more efficient (StataCorp 2001) than the two-step procedure. Identification is achieved by including variables $\left(x_{i}\right)$, such as household size and household non-wage income, in the selection equation but not in the wage equation. Justification for the use of these variables is that they affect wage employment participation probabilities through changing the opportunity cost of being in the wage labour force, but an employer is unlikely to pay a different wage rate depending on one's household size or nonlabour income.

Household size may affect wage employment participation because low productivity and limited arable land in the agricultural sector have resulted in labour surplus in the agricultural sector if households have more members. Therefore, household size relates to labour surplus and affects wage employment participation. Households with higher non-wage incomes from self-employment, given the same household size, family businesses and farming, should have a higher reservation wage and hence may not send their members out to work in the wage employment sector. Therefore, household size and non-wage income are likely to affect significantly the probability of being wage-earners in the case of Vietnam.

\section{Estimation Results}

The descriptive statistics show that on average educational attainment of wage earners in Vietnam was about nine to ten years of schooling, except slightly lower in the 2002 sample (Table 1). ${ }^{5}$ Non-wage earners' education attainment is lower than that of wage earners in all years. The average hourly wage rate was 2,420 VND (US\$0.176) in 1998 and in nominal terms had risen to 26,320 VND (US\$ 1.238) by 2014, or by 10.9 times, and by seven times in the US\$ terms. Interestingly, the share of university-graduated workers in the wage-earner subsample increased significantly after the 2008 survey round: the share rose more than threefold, from $7.2 \%$ to $22.9 \%$ between 2008 and 2014 .

\subsection{Returns to Education}

\section{a. Baseline Estimates}

Table 2 contains the basic earnings function estimates. All coefficients are statistically significant at the one percent level. The coefficient on years of schooling implies an average private rate of return to another year of schooling of $2.9 \%$ in 1998 rising continuously yearby-year to a peak of $9.5 \%$ in 2008 , then declining to $7.2 \%$ in $2010,6 \%$ in 2012 and to $5.7 \%$ in 2014. These results obviously show the increasing returns to schooling during the 2000s then declining after the GFC in 2008.

5 Significant larger sample size and quite different sampling strategy of VHLSS2002 result in slightly lower years of schooling 
Table 1: Means of Some Main Variables for Wage Earner Sub-sample 1998-2014

\begin{tabular}{lrrrrrrrr}
\hline Year & 1998 & 2002 & 2004 & 2006 & 2008 & 2010 & 2012 & 2014 \\
\hline Sex (M=1) & 0.60 & 0.63 & 0.61 & 0.61 & 0.61 & 0.60 & 0.59 & 0.58 \\
Age (years) & 30.8 & 32.1 & 32.8 & 33.2 & 33.8 & 34.1 & 34.3 & 34.7 \\
Experience (years) & 14.6 & 15.8 & 15.8 & 15.9 & 16.3 & 16.9 & 17.1 & 16.8 \\
Household size & 6.1 & 5.7 & 5.6 & 5.4 & 5.3 & 4.9 & 5.0 & 4.9 \\
Household non-wage & 1.36 & 1.09 & 1.50 & 1.98 & 3.04 & 2.94 & 3.88 & 4.25 \\
income & & & & & & & & \\
Schooling year & 9.2 & 8.2 & 9.7 & 9.8 & 10.0 & 9.5 & 9.4 & 10.4 \\
Vocational share (\%) & 6.9 & 10.2 & 16.8 & 18.0 & 14.9 & 15.4 & 16.7 & 14.8 \\
University share (\%) & $6.0 \%$ & 6.0 & 7.2 & 7.2 & 12.0 & 14.6 & 19.4 & 22.9 \\
Hourly income in logs & 0.68 & 0.99 & 1.24 & 1.51 & 1.93 & 2.5 & 2.87 & 3.09 \\
Hourly income & 2.42 & 3.95 & 4.61 & 5.94 & 9.24 & 15.6 & 21.36 & 26.32 \\
Non-wage earner & 7.8 & 7.5 & 8.5 & 8.7 & 8.9 & 8.2 & 7.8 & 8.5 \\
schooling year & & & & & & & & \\
Income of non- & 1.74 & 1.95 & 2.62 & 3.34 & 5.15 & 6.03 & 8.1 & 9.3 \\
wager HHs & & & & & & & & \\
Wage earners (\%) & 16.6 & 32.6 & 34.4 & 35.1 & 35.3 & 37.6 & 34.9 & 36.5 \\
\hline Notes
\end{tabular}

Notes

Hourly wage rates are in 1,000 Vietnam Dong. The average exchange rate was 13,765 Dong/USD in 1998, 15,244 in $2002 ; 15,705$ in $2004 ; 15,965$ in $2006 ; 16,481$ in $2008 ; 18,983$ in $2010 ; 20,919$ in $2012 ; 21,259$ in 2014. Samples exclude several extreme outliers. Non-wage income is in VND million.

Table 2: Baseline Estimates Using OLS 1998-2014

\begin{tabular}{lrrrrrrrr}
\hline & 1998 & 2002 & 2004 & 2006 & 2008 & 2010 & 2012 & 2014 \\
\hline school year & 0.029 & 0.076 & 0.084 & 0.088 & 0.095 & 0.072 & 0.060 & 0.057 \\
& $(7.64)^{* *}$ & $(43.96)^{* *}$ & $(34.41)^{* *}$ & $(38.99)^{* *}$ & $(39.62)^{* *}$ & $(35.88)^{* *}$ & $(39.51)^{* *}$ & $(40.80)^{* *}$ \\
exp & 0.015 & 0.018 & 0.027 & 0.030 & 0.040 & 0.042 & 0.041 & 0.045 \\
& $(2.90)^{* *}$ & $(7.43)^{* *}$ & $(8.28)^{* *}$ & $(10.66)^{* *}$ & $(13.97)^{* *}$ & $(16.15)^{* *}$ & $(17.01)^{* *}$ & $(21.33)^{* *}$ \\
exp2 & -0.001 & -0.0001 & -0.001 & -0.001 & -0.001 & -0.001 & -0.001 & -0.001 \\
& $(3.69)^{* *}$ & $(6.19)^{* *}$ & $(6.91)^{* *}$ & $(8.52)^{* *}$ & $(12.22)^{* *}$ & $(13.63)^{* *}$ & $(14.29)^{* *}$ & $(17.50)^{* *}$ \\
sex $(\mathrm{M}=1)$ & 0.138 & 0.161 & 0.128 & 0.137 & 0.182 & 0.167 & 0.179 & 0.117 \\
& $(4.55)^{* *}$ & $(10.89)^{* *}$ & $(6.40)^{* *}$ & $(7.68)^{* *}$ & $(10.14)^{* *}$ & $(10.07)^{* *}$ & $(13.04)^{* *}$ & $(8.23)^{* *}$ \\
Constant & 0.294 & 0.139 & 0.215 & 0.406 & 0.644 & 1.350 & 1.871 & 2.063 \\
& $(6.01)^{* *}$ & $(5.80)^{* *}$ & $(6.14)^{* *}$ & $(12.46)^{* *}$ & $(18.62)^{* *}$ & $(40.51)^{* *}$ & $(72.73)^{* *}$ & $(79.98)^{* *}$ \\
Observations & 3,244 & 26,268 & 7,177 & 7,436 & 7,532 & 7,166 & 7,758 & 7,868 \\
R-squared & 0.04 & 0.15 & 0.20 & 0.23 & 0.25 & 0.25 & 0.28 & 0.28 \\
Prob > F & 0.0000 & 0.0000 & 0.0000 & 0.0000 & 0.0000 & 0.0000 & 0.0000 & 0.0000 \\
F statistics & 23.85 & 550.93 & 328.97 & 410.94 & 444.05 & 355.06 & 464.01 & 491.74 \\
\hline
\end{tabular}

Notes

Robust $t$-statistics in parentheses (corrected for sampling weights), statistically significant at $10 \%(+)$, at $5 \%(*)$, and at $1 \%(* *)$. The dependent variable is the hourly wage in logs. The hourly wage is measured in VND 1,000 (and for all tables hereafter). 


\section{b. Heckman Maximum Likelihood Estimates}

To overcome selectivity bias, the Heckman selection-correction model is employed. After correcting for sample selection bias, the estimated rates of return to education are somewhat higher than in the OLS estimates reported in Table 2. The OLS estimate is downward-biased because the OLS uses only the wage-earner subsample; wage-earners may have better ability and also have spent more years at school (Table 1).

The selection-corrected estimates show a consistent trend similar to the OLS estimates, which shows rising returns up to 2008 then declining thereafter. The Heckman selection model estimates are reported in Table 3. The estimated rate of returns rose from $3.8 \%$ in 1998 to $10.4 \%$ in 2008 and then declined gradually to $6.2 \%$ by 2014 . The returns declined to low level similar to those of the early 2000s.

All the statistics of the Heckman selection equation, such as sigma, lambda and rho, are highly statistically significant, supporting an appropriate application of the model. The positive coefficients on years of schooling in the selection equations show a positive effect of education, which is omitted from the standard wage equations, on wage labour market participation.

There exists a substantial rise in the effect of education on the likelihood of wage labour market participation until 2008. From 2008 onwards, the role of education on wage labour market participation has been stable. In other words, workers with higher education have an increasingly higher likelihood of having wage jobs up to 2008 then stable thereafter. It is also notable that the overall rise in the likelihood of wage labour market participation increased from $16.6 \%$ in 1998 to $36.5 \%$ by 2014 .

The rapid increase in the probability of being in wage work was up to 2008, and then remained the same from 2008 onwards. This reflects a slowing down in economic structural changes in Vietnam after the Global Financial Crisis. Availability of other non-wage employment from household business, self-employment, and farming, which generates household non-wage incomes, reduces the likelihood of wage labour market participation. However, the negative effect of non-wage income on wage labour market participation has faded out during the 2000s. 
Table 3: Heckman Selection Model Estimates

\begin{tabular}{|c|c|c|c|c|c|c|c|c|c|c|c|c|c|c|c|c|}
\hline & \multicolumn{2}{|c|}{1998} & \multicolumn{2}{|c|}{2002} & \multicolumn{2}{|c|}{2004} & \multicolumn{2}{|c|}{2006} & \multicolumn{2}{|c|}{2008} & \multicolumn{2}{|c|}{2010} & \multicolumn{2}{|c|}{2012} & \multicolumn{2}{|c|}{2014} \\
\hline & wage & selection & wage & selection & wage & selection & wage & selection & wage & selection & wage & selection & wage & selection & wage & selection \\
\hline $\begin{array}{l}\text { Schooling } \\
\text { years }\end{array}$ & $\begin{array}{r}0.0381 * * \\
(0.0041)\end{array}$ & $\begin{array}{r}0.0500^{* *} \\
(0.0040)\end{array}$ & $\begin{array}{r}0.0772^{* * *} \\
(0.0018)\end{array}$ & $\begin{array}{r}0.0386 * * \\
(0.0025)\end{array}$ & $\begin{array}{r}0.0929 * * \\
(0.0031)\end{array}$ & $\begin{array}{r}0.0852^{* *} \\
(0.0035)\end{array}$ & $\begin{array}{r}0.0966 * * \\
(0.0030)\end{array}$ & $\begin{array}{r}0.0882 * * \\
(0.0036)\end{array}$ & $\begin{array}{r}0.1038 * * \\
(0.0032)\end{array}$ & $\begin{array}{r}0.0870^{* *} \\
(0.0034)\end{array}$ & $\begin{array}{r}0.0844 * * \\
(0.0033)\end{array}$ & $\begin{array}{r}0.0918 * * \\
(0.0033)\end{array}$ & $\begin{array}{r}0.0717^{* *} \\
(0.0042)\end{array}$ & $\begin{array}{r}0.0904 * * \\
(0.0024)\end{array}$ & $\begin{array}{r}0.0619 * * \\
(0.0017)\end{array}$ & $\begin{array}{r}0.0925 * * \\
(0.0027)\end{array}$ \\
\hline Experience & $\begin{array}{r}0.0155^{* *} \\
(0.0052)\end{array}$ & $\begin{array}{r}-0.0000 \\
(0.0035)\end{array}$ & $\begin{array}{r}0.0247 * * \\
(0.0029)\end{array}$ & $\begin{array}{r}0.0810 * * \\
(0.0021)\end{array}$ & $\begin{array}{r}0.0402 * * \\
(0.0041)\end{array}$ & $\begin{array}{r}0.0909 * * \\
(0.0032)\end{array}$ & $\begin{array}{r}0.0436 * * \\
(0.0036)\end{array}$ & $\begin{array}{r}0.0978^{* *} \\
(0.0032)\end{array}$ & $\begin{array}{r}0.0555^{* *} \\
(0.0041)\end{array}$ & $\begin{array}{r}0.1037 * * \\
(0.0031)\end{array}$ & $\begin{array}{r}0.0600 * * \\
(0.0045)\end{array}$ & $\begin{array}{r}0.0980^{* *} \\
(0.0034)\end{array}$ & $\begin{array}{r}0.0577 * * \\
(0.0056)\end{array}$ & $\begin{array}{r}0.1044 * * \\
(0.0036)\end{array}$ & $\begin{array}{r}0.0533 * * \\
(0.0026)\end{array}$ & $\begin{array}{r}0.1097 * * \\
(0.0037)\end{array}$ \\
\hline Exp2 & $\begin{array}{r}-0.0006^{* *} \\
(0.0002)\end{array}$ & $\begin{array}{r}-0.0002 * * \\
(0.0001)\end{array}$ & $\begin{array}{r}-0.0006^{* *} * \\
(0.0001)\end{array}$ & $\begin{array}{r}-0.0023 * * \\
(0.0001)\end{array}$ & $\begin{array}{r}-0.0010 * * \\
(0.0001)\end{array}$ & $\begin{array}{r}-0.0025^{* *} \\
(0.0001)\end{array}$ & $\begin{array}{r}-0.0010^{* *} \\
(0.0001)\end{array}$ & $\begin{array}{r}-0.0026 * * \\
(0.0001)\end{array}$ & $\begin{array}{r}-0.0014 * * \\
(0.0001)\end{array}$ & $\begin{array}{r}-0.0027 * * \\
(0.0001)\end{array}$ & $\begin{array}{r}-0.0014 * * \\
(0.0001)\end{array}$ & $\begin{array}{r}-0.0026 * * \\
(0.0001)\end{array}$ & $\begin{array}{r}-0.0013 * * \\
(0.0001)\end{array}$ & $\begin{array}{r}-0.0024 * * \\
(0.0001)\end{array}$ & $\begin{array}{r}-0.0011^{* *} \\
(0.0001)\end{array}$ & $\begin{array}{r}-0.0025^{* * *} \\
(0.0001)\end{array}$ \\
\hline Sex & $\begin{array}{r}0.2448^{* *} \\
(0.0340)\end{array}$ & $\begin{array}{r}0.4703^{* *} \\
(0.0240)\end{array}$ & $\begin{array}{r}0.2018^{* *} \\
(0.0173)\end{array}$ & $\begin{array}{r}0.5052^{* *} \\
(0.0143)\end{array}$ & $\begin{array}{r}0.1872 * * \\
(0.0236)\end{array}$ & $\begin{array}{r}0.4258^{* *} \\
(0.0222)\end{array}$ & $\begin{array}{r}0.1956^{* *} \\
(0.0206)\end{array}$ & $\begin{array}{r}0.4297 * * \\
(0.0218)\end{array}$ & $\begin{array}{r}0.2433^{* *} \\
(0.0214)\end{array}$ & $\begin{array}{r}0.4341^{* *} \\
(0.0213)\end{array}$ & $\begin{array}{r}0.2400^{* * *} \\
(0.0222)\end{array}$ & $\begin{array}{r}0.4181^{* *} \\
(0.0223)\end{array}$ & $\begin{array}{r}0.2343^{* *} \\
(0.0226)\end{array}$ & $\begin{array}{r}0.3627^{* *} \\
(0.0209)\end{array}$ & $\begin{array}{r}0.1389^{* *} \\
(0.0149)\end{array}$ & $\begin{array}{r}0.3594^{* *} \\
(0.0211)\end{array}$ \\
\hline $\begin{array}{l}\text { Household } \\
\text { size }\end{array}$ & & $\begin{array}{r}0.0009 \\
(0.0071)\end{array}$ & & $\begin{array}{r}0.0446 * * \\
(0.0054)\end{array}$ & & $\begin{array}{r}0.0469 * * \\
(0.0074)\end{array}$ & & $\begin{array}{r}0.0460^{* * *} \\
(0.0087)\end{array}$ & & $\begin{array}{r}0.0446 * * \\
(0.0076)\end{array}$ & & $\begin{array}{r}0.0343^{* *} \\
(0.0082)\end{array}$ & & $\begin{array}{r}0.0396 * * \\
(0.0096)\end{array}$ & & $\begin{array}{r}0.0328^{* * *} \\
(0.0101)\end{array}$ \\
\hline $\begin{array}{l}\text { Non_wage } \\
\text { income }^{(a)}\end{array}$ & & $\begin{array}{r}-0.0752 * * \\
(0.0098)\end{array}$ & & $\begin{array}{r}-0.2468 * * \\
(0.0224)\end{array}$ & & $\begin{array}{r}-0.1811 * * \\
(0.0124)\end{array}$ & & $\begin{array}{r}-0.1053 * * \\
(0.0114)\end{array}$ & & $\begin{array}{r}-0.0632 * * \\
(0.0061)\end{array}$ & & $\begin{array}{r}-0.0758^{* *} \\
(0.0069)\end{array}$ & & $\begin{array}{r}-0.0251 * * \\
(0.0085)\end{array}$ & & $\begin{array}{r}-0.0493 * * \\
(0.0089)\end{array}$ \\
\hline Constant & $\begin{array}{r}-0.2649 * * \\
(0.0891)\end{array}$ & $\begin{array}{r}-1.5129 * * \\
(0.0657)\end{array}$ & $\begin{array}{r}-0.0542 \\
(0.0503)\end{array}$ & $\begin{array}{r}-1.2933^{* *} \\
(0.0406)\end{array}$ & $\begin{array}{c}-0.1664 * \\
(0.0797)\end{array}$ & $\begin{array}{r}-1.7212 * * \\
(0.0597)\end{array}$ & $\begin{array}{r}0.0182 \\
(0.0747)\end{array}$ & $\begin{array}{r}-1.8462 * * \\
(0.0636)\end{array}$ & $\begin{array}{r}0.2281 * * \\
(0.0864)\end{array}$ & $\begin{array}{r}-1.8921 * * \\
(0.0591)\end{array}$ & $\begin{array}{r}0.8434 * * \\
(0.1021)\end{array}$ & $\begin{array}{r}-1.8107 * * \\
(0.0581)\end{array}$ & $\begin{array}{r}1.3931 * * \\
(0.1520)\end{array}$ & $\begin{array}{r}-2.1020^{* * *} \\
(0.0432)\end{array}$ & $\begin{array}{r}1.8551^{* *} \\
(0.0466)\end{array}$ & $\begin{array}{r}-1.9636 * * \\
(0.0501)\end{array}$ \\
\hline rho & & $\begin{array}{r}0.3414 * * \\
(0.0417)\end{array}$ & & $\begin{array}{r}0.1476 * * \\
(0.0331)\end{array}$ & & $\begin{array}{r}0.28723 * * \\
(0.0498)\end{array}$ & & $\begin{array}{r}0.3099 * * \\
(0.0490)\end{array}$ & & $\begin{array}{r}0.3209 * * \\
(0.0551)\end{array}$ & & $\begin{array}{r}0.4208 * * \\
(0.0699)\end{array}$ & & $\begin{array}{r}0.4149 * * \\
(0.1120)\end{array}$ & & $\begin{array}{r}0.1974 * * \\
(0.0360)\end{array}$ \\
\hline Sigma & & $\begin{array}{r}0.8345^{* *} \\
(0.0196)\end{array}$ & & $\begin{array}{r}0.8123^{* * *} \\
(0.0072)\end{array}$ & & $\begin{array}{r}0.7082^{* *} \\
(0.0111)\end{array}$ & & $\begin{array}{r}0.6610^{* * *} \\
(0.0096)\end{array}$ & & $\begin{array}{r}0.6780^{* *} \\
(0.0115)\end{array}$ & & $\begin{array}{r}0.6078 * * \\
(0.0159)\end{array}$ & & $\begin{array}{r}0.5473 * * \\
(0.0204)\end{array}$ & & $\begin{array}{r}0.5096 * * \\
(0.0067)\end{array}$ \\
\hline $\operatorname{Lambda}(\lambda)$ & & $\begin{array}{r}0.2850 * * \\
(0.0380)\end{array}$ & & $\begin{array}{r}0.1200 * * \\
(0.0273)\end{array}$ & & $\begin{array}{r}0.2035^{* *} \\
(0.0372)\end{array}$ & & $\begin{array}{r}0.2048^{* * *} \\
(0.0346)\end{array}$ & & $\begin{array}{r}0.2176^{* * *} \\
(0.0400)\end{array}$ & & $\begin{array}{r}0.2558^{* * *} \\
(0.0480)\end{array}$ & & $\begin{array}{r}0.2271^{* *} \\
(0.0693)\end{array}$ & & $\begin{array}{r}0.1006^{* *} \\
(0.0188)\end{array}$ \\
\hline Prob $>F$ & 0.0000 & & 0.0000 & & 0.0000 & & 0.0000 & & 0.0000 & & 0.0000 & & 0.0000 & & 0.0000 & \\
\hline Obs & 3,244 & 20,627 & 26,268 & 80,575 & 7,177 & 20,866 & 7,436 & 21,209 & 7,532 & 21,311 & 7,166 & 21,630 & 7,758 & 31,150 & 7,868 & 30,721 \\
\hline
\end{tabular}

Notes

Robust standard errors in parentheses.

* significant at 5\%

** significant at $1 \%$

(a) Household non-wage income is divided by 10,000 . 


\subsection{Tests for the Declining Returns since 2008}

In a previous study, Doan and Gibson (2012) showed a robust upward trend of the returns to schooling from 1998 and 2008. In the current study, we also observe a consistent increasing trend of returns up to 2008. However, we observe that the trend started falling after 2008 (Tables 2 and 3). To validate the comparison, and consolidate the finding of falling returns after 2008, we use pooled data and the interaction terms discussed in Section 2. Specifically, we pooled VHLSS2008 with, one after the other, VHLSS2010, VHLSS2012 and VHLSS2014 to set up pooled datasets.

The interaction terms are used to test whether the returns to schooling are not significantly different from zero over time. The hypothesis is that the slope of the hourly wage, in logarithm $(\ln Y)$, with respect to years of schooling $(S)$ is the same for both base year and the compared year (the second year).

The OLS results of the pooled Mincerian earnings equation estimation are presented in Table 4. The first three columns are estimated rates of returns to schooling for $2008\left(\beta_{1}\right)$ and the interaction terms for the change in rate of returns between the base year 2008 and the comparison or the second year $\left(\alpha_{1}\right)$. In the first column, the return to schooling for year 2008 is $9.46 \%$, and the return for 2010 is $7.24 \%$ (or $9.46 \%-2.22 \%$ ). In the second column, the return for 2012 is $6 \%$ (or $9.46 \%-3.46 \%$ ). Likewise, the return for 2014 is $5.69 \%$ (or $9.46 \%$ $3.77 \%$ ). The tests for difference in the returns between the compared year and the base year of 2008 are all statistically significant at the $1 \%$ level (the test for the hypothesis $\mathrm{H}: \alpha_{1}=0$ ). These estimates show that the return is declining between 2008 and 2014.

The estimates in columns 1, 4 and 5 of Table 4 enable us to test the pace of falling returns to schooling across years. The pace of the decline was $2.22 \%$ between 2008 and 2010, $1.24 \%$ between 2010 and 2012 and only $0.3 \%$ between 2012 and 2014 but the coefficient of the interaction term in column 5 is not statistically significant. This shows that the pace of the falling returns has been slowing in recent years, and seems to pause in 2014. We repeat the test $\left(\mathrm{H}: \alpha_{1}=0\right)$ with Heckman selection model estimation in Table 5. Although the magnitude of the interaction terms changed slightly, the declining trend is clear and consistent with the OLS estimates in Table 4.

The estimates on the interaction terms are all negative but their magnitude becomes smaller for later years (2012 and 2014) suggesting a clear trend of falling returns to schooling from 2008 to 2014. However, the pace of decline in the rates of returns has slowed in recent years. The interaction term coefficient of schooling year and the second year for 2014 is insignificantly different from zero, implying a trough may have been reached. 
Table 4: Testing the Downward Trend in Interaction Term Regressions

(OLS estimates)

\begin{tabular}{|c|c|c|c|c|c|}
\hline & $2008 / 2010$ & $2008 / 2012$ & $2008 / 2014$ & $2010 / 2012$ & $2012 / 2014$ \\
\hline \multirow[t]{2}{*}{ Second year dummy $\left(\alpha_{0}\right)$} & & & & 0.5218 & 0.1916 \\
\hline & $(14.70)^{* *}$ & $(28.49)^{* *}$ & $(32.91)^{* *}$ & $(12.40)^{* *}$ & $(5.26)^{* *}$ \\
\hline \multirow{2}{*}{ School year $\left(\beta_{1}\right)$} & 0.0946 & 0.0946 & 0.0946 & 0.0723 & 0.0599 \\
\hline & $(39.62) * *$ & $(39.62)^{* *}$ & $(39.62)^{* *}$ & $(35.88)^{* *}$ & $(39.51)^{* *}$ \\
\hline School year & -0.0222 & -0.0346 & -0.0377 & -0.0124 & -0.0030 \\
\hline$*$ second year $\left(\alpha_{1}\right)$ & $(7.12)^{* *}$ & $(12.25)^{* *}$ & $(13.63)^{* *}$ & $(4.92)^{* *}$ & $(1.47)$ \\
\hline \multirow[t]{2}{*}{$\operatorname{Exp}\left(\beta_{2}\right)$} & 0.0400 & 0.0400 & 0.0400 & 0.0418 & 0.0406 \\
\hline & $(13.97)^{* *}$ & $(13.97)^{* *}$ & $(13.97)^{* *}$ & $(16.15)^{* *}$ & $(17.01)^{* *}$ \\
\hline \multirow[t]{2}{*}{ Exp ${ }^{\star}$ second year $\left(\alpha_{2}\right)$} & 0.0018 & 0.0005 & 0.0054 & -0.0012 & 0.0048 \\
\hline & $(0.46)$ & $(0.14)$ & $(1.51)$ & $(0.35)$ & $(1.51)$ \\
\hline \multirow[t]{2}{*}{$\operatorname{Exp} 2\left(\beta_{2}\right)$} & -0.0010 & -0.0010 & -0.0010 & -0.0009 & -0.0009 \\
\hline & $(12.22)^{* *}$ & $(12.22)^{* *}$ & $(12.22)^{* *}$ & $(13.63)^{* *}$ & $(14.29) * *$ \\
\hline \multirow[t]{2}{*}{ Exp $2 \star$ second year $\left(\alpha_{3}\right)$} & 0.0001 & 0.0001 & 0.0000 & 0.0000 & -0.0001 \\
\hline & $(0.49)$ & $(0.93)$ & $(0.11)$ & $(0.46)$ & $(1.01)$ \\
\hline \multirow[t]{2}{*}{$\operatorname{Sex}\left(\beta_{3}\right)$} & 0.1818 & 0.1818 & 0.1818 & 0.1675 & 0.1794 \\
\hline & $(10.14)^{* *}$ & $(10.14)^{* *}$ & $(10.14)^{* *}$ & $(10.07)^{* *}$ & $(13.04)^{* *}$ \\
\hline \multirow[t]{2}{*}{ Sex*school year $\left(\alpha_{4}\right)$} & -0.0144 & -0.0025 & -0.0648 & 0.0119 & -0.0623 \\
\hline & $(0.59)$ & $(0.11)$ & $(2.83)^{* *}$ & $(0.55)$ & $(3.15)^{* *}$ \\
\hline \multirow[t]{2}{*}{ Constant } & 0.6437 & 0.6437 & 0.6437 & 1.3496 & 1.8714 \\
\hline & $(18.62)^{* *}$ & $(18.62)^{* *}$ & $(18.62)^{* *}$ & $(40.51)^{* *}$ & $(72.73)^{* *}$ \\
\hline R-squared & 0.34 & 0.48 & 0.56 & 0.32 & 0.30 \\
\hline F-stats & 563.19 & 1123.87 & 1617.87 & 503.27 & 510.55 \\
\hline Prob $>$ F & 0.0000 & 0.0000 & 0.0000 & 0.0000 & 0.0000 \\
\hline Test $\left(\alpha_{1}=0\right)$ & 0.0000 & 0.0000 & 0.0000 & 0.0000 & 0.1408 \\
\hline Test $: \alpha_{0}=\alpha_{1}=\alpha_{2}=\alpha_{3}=\alpha_{4}$ & 0.0000 & 0.0000 & 0.0000 & 0.0000 & 0.0033 \\
\hline Observations & 14,698 & 15,290 & 15,400 & 14,924 & 15,626 \\
\hline
\end{tabular}

Notes

Robust $t$ statistics in parentheses, corrected for sampling weights.

* significant at $5 \%$

** significant at $1 \%$. 
Table 5: Testing the Trend in Interaction Term Regressions (Heckman ML Estimates)

\begin{tabular}{|c|c|c|c|c|c|c|}
\hline & 2008 & 010 & 2010 & 012 & 2012 & 014 \\
\hline & wage & selection & wage & selection & wage & selection \\
\hline Second year dummy & $\begin{array}{r}0.6895 \\
(13.71)^{* *}\end{array}$ & $\begin{array}{r}0.0892 \\
(1.08)\end{array}$ & $\begin{array}{r}0.4904 \\
(10.95)^{* *}\end{array}$ & $\begin{array}{r}-0.2861 \\
(3.96)^{* *}\end{array}$ & $\begin{array}{r}0.1987 \\
(5.37)^{* *}\end{array}$ & $\begin{array}{l}0.1443 \\
(2.17)^{*}\end{array}$ \\
\hline School year & $\begin{array}{r}0.1042 \\
(35.63)^{* *}\end{array}$ & $\begin{array}{r}0.0873 \\
(25.32)^{* *}\end{array}$ & $\begin{array}{r}0.0839 \\
(26.56)^{* *}\end{array}$ & $\begin{array}{r}0.0922 \\
(27.81)^{* *}\end{array}$ & $\begin{array}{r}0.0682 \\
(27.90)^{* *}\end{array}$ & $\begin{array}{r}0.0901 \\
(36.47)^{* *}\end{array}$ \\
\hline $\begin{array}{l}\text { School year } \\
* \text { Second year }\end{array}$ & $\begin{array}{r}-0.0210 \\
(6.31)^{* *}\end{array}$ & $\begin{array}{r}0.0037 \\
(0.79)\end{array}$ & $\begin{array}{r}-0.0113 \\
(4.12)^{* *}\end{array}$ & $\begin{array}{r}-0.0020 \\
(0.49)\end{array}$ & $\begin{array}{r}-0.0034 \\
(1.57)\end{array}$ & $\begin{array}{r}0.0025 \\
(0.68)\end{array}$ \\
\hline Exp & $\begin{array}{r}0.0563 \\
(15.60)^{* *}\end{array}$ & $\begin{array}{r}0.1039 \\
(33.34)^{* *}\end{array}$ & $\begin{array}{r}0.0593 \\
(13.44)^{* *}\end{array}$ & $\begin{array}{r}0.0982 \\
(28.92)^{* *}\end{array}$ & $\begin{array}{r}0.0525 \\
(16.39)^{* *}\end{array}$ & $\begin{array}{r}0.1047 \\
(29.77)^{* *}\end{array}$ \\
\hline Exp * Second year & $\begin{array}{r}0.0018 \\
(0.45)\end{array}$ & $\begin{array}{r}-0.0060 \\
(1.31)\end{array}$ & $\begin{array}{r}-0.0002 \\
(0.06)\end{array}$ & $\begin{array}{r}0.0060 \\
(1.23)\end{array}$ & $\begin{array}{c}0.0054 \\
(1.69)+\end{array}$ & $\begin{array}{r}0.0048 \\
(0.96)\end{array}$ \\
\hline Exp2 & $\begin{array}{r}-0.0014 \\
(14.13)^{* *}\end{array}$ & $\begin{array}{r}-0.0027 \\
(32.18) * *\end{array}$ & $\begin{array}{r}-0.0014 \\
(11.75)^{* *}\end{array}$ & $\begin{array}{r}-0.0026 \\
(28.51)^{* *}\end{array}$ & $\begin{array}{r}-0.0011 \\
(14.73)^{* *}\end{array}$ & $\begin{array}{r}-0.0024 \\
(25.09)^{* *}\end{array}$ \\
\hline Exp $2 *$ Second year & $\begin{array}{r}0.0001 \\
(0.52)\end{array}$ & $\begin{array}{r}0.0002 \\
(1.30)\end{array}$ & $\begin{array}{r}0.0001 \\
(0.72)\end{array}$ & $\begin{array}{r}0.0002 \\
(1.49)\end{array}$ & $\begin{array}{r}-0.0001 \\
(1.22)\end{array}$ & $\begin{array}{r}-0.0001 \\
(0.96)\end{array}$ \\
\hline Sex & $\begin{array}{r}0.2466 \\
(12.29)^{* *}\end{array}$ & $\begin{array}{r}0.4342 \\
(20.39)^{* *}\end{array}$ & $\begin{array}{r}0.2371 \\
(10.72)^{* *}\end{array}$ & $\begin{array}{r}0.4184 \\
(18.74)^{* *}\end{array}$ & $\begin{array}{r}0.2175 \\
(13.50)^{* *}\end{array}$ & $\begin{array}{r}0.3641 \\
(17.51)^{* *}\end{array}$ \\
\hline Sex $*$ Second year & $\begin{array}{r}-0.0144 \\
(0.58)\end{array}$ & $\begin{array}{r}-0.0150 \\
(0.49)\end{array}$ & $\begin{array}{r}0.0016 \\
(0.07)\end{array}$ & $\begin{array}{c}-0.0564 \\
(1.86)+\end{array}$ & $\begin{array}{r}-0.0659 \\
(3.29)^{* *}\end{array}$ & $\begin{array}{r}-0.0066 \\
(0.22)\end{array}$ \\
\hline Household size & & $\begin{array}{r}0.0439 \\
(5.86) * *\end{array}$ & & $\begin{array}{r}0.0345 \\
(4.20)^{* *}\end{array}$ & & $\begin{array}{r}0.0410 \\
(4.54)^{* *}\end{array}$ \\
\hline $\begin{array}{l}\text { Household size } \\
\text { * Second year }\end{array}$ & & $\begin{array}{r}-0.0095 \\
(0.84)\end{array}$ & & $\begin{array}{r}0.0048 \\
(0.40)\end{array}$ & & $\begin{array}{r}-0.0095 \\
(0.71)\end{array}$ \\
\hline Non-wage income & & $\begin{array}{r}-0.0631 \\
(10.52)^{* *}\end{array}$ & & $\begin{array}{r}-0.0761 \\
(11.35)^{* *}\end{array}$ & & $\begin{array}{r}-0.0258 \\
(3.10) * *\end{array}$ \\
\hline $\begin{array}{l}\text { Non-wage income } \\
* \text { Second year }\end{array}$ & & $\begin{array}{r}-0.0132 \\
(1.50)\end{array}$ & & $\begin{array}{r}0.0512 \\
(5.30)^{* *}\end{array}$ & & $\begin{array}{l}-0.0227 \\
(1.92)+\end{array}$ \\
\hline Constant & $\begin{array}{r}0.2059 \\
(3.02)^{* *}\end{array}$ & $\begin{array}{r}-1.8917 \\
(32.02)^{* *}\end{array}$ & $\begin{array}{r}0.8645 \\
(8.51)^{* *}\end{array}$ & $\begin{array}{r}-1.8142 \\
(31.32)^{* *}\end{array}$ & $\begin{array}{r}1.5378 \\
(21.17)^{* *}\end{array}$ & $\begin{array}{r}-2.1052 \\
(47.76) * *\end{array}$ \\
\hline $\begin{array}{l}\text { Observations } \\
\text { Lambda }\left(\lambda=\rho^{*} \sigma\right)\end{array}$ & & $\begin{array}{r}42,941 \\
0.2294 \\
(0.0295)^{* *}\end{array}$ & & $\begin{array}{r}52,780 \\
0.2452 \\
(0.0480)^{* *}\end{array}$ & & $\begin{array}{r}61,871 \\
0.1582 \\
(0.0306)^{* *}\end{array}$ \\
\hline
\end{tabular}

\section{Notes}

Robust standard errors in parentheses.

* significant at 5\%

** significant at $1 \%$

(a) household non-wage income is divided by 10,000 . 


\subsection{Who Contributed to the Fall in Returns?}

The above estimates and the trend raise the question 'what drives the trend?'. To see if the supply of higher education played a role in the decline in returns, we examine how income by educational level changed over time in relation to the income of other education groups. We remove two rounds of the survey, 2002 and 2008. The 2002 survey round has a much larger sample size which includes more poorer households (see Table 1). The 2008 survey round was affected by the GFC. In comparison with non-education group, hourly income of primary and lower secondary groups has been fairly stable over the period, while hourly income of higher education groups has been declining. The sharp falls were observed in the university group, from eight times in 1998 to 2.4 times in 2014, then the vocational group, from three fold to 1.6 times (Tables 6 and 7).

Table 6: Mean Hourly Income by Education Level for Whole Subsample (Corrected For Sampling Weight (VND1,000))

\begin{tabular}{|c|c|c|c|c|c|c|c|c|c|c|c|c|}
\hline \multirow[t]{2}{*}{ Year } & \multicolumn{2}{|c|}{ No Ed } & \multicolumn{2}{|c|}{ Primary } & \multicolumn{2}{|c|}{ Lower second } & \multicolumn{2}{|c|}{ Upper second } & \multicolumn{2}{|c|}{ Vocational } & \multicolumn{2}{|c|}{ University } \\
\hline & Mean & SE & Mean & SE & Mean & SE & Mean & SE & Mean & SE & Mean & SE \\
\hline 1998 & 0.45 & 0.03 & 0.45 & 0.01 & 0.56 & 0.01 & 1.13 & 0.04 & 1.35 & 0.07 & 3.56 & 0.22 \\
\hline 2002 & 0.76 & 0.04 & 0.96 & 0.03 & 0.94 & 0.02 & 1.10 & 0.03 & 4.28 & 0.25 & 7.70 & 0.34 \\
\hline 2004 & 3.06 & 0.27 & 3.37 & 0.08 & 3.37 & 0.07 & 5.27 & 0.20 & 6.36 & 0.13 & 10.38 & 0.34 \\
\hline 2006 & 3.89 & 0.40 & 4.27 & 0.08 & 4.46 & 0.08 & 6.37 & 0.21 & 8.22 & 0.18 & 13.83 & 0.37 \\
\hline 2008 & 8.29 & 0.82 & 6.29 & 0.13 & 6.54 & 0.12 & 9.25 & 0.33 & 11.13 & 0.24 & 21.01 & 0.61 \\
\hline 2010 & 10.66 & 0.59 & 10.85 & 0.24 & 11.26 & 0.21 & 12.80 & 0.38 & 16.97 & 0.57 & 30.29 & 1.32 \\
\hline 2012 & 14.03 & 0.34 & 15.43 & 0.19 & 16.69 & 0.24 & 19.83 & 0.53 & 23.17 & 0.46 & 36.40 & 1.01 \\
\hline 2014 & 17.25 & 0.34 & 19.29 & 0.32 & 20.63 & 0.47 & 23.98 & 0.62 & 28.31 & 0.62 & 41.32 & 0.74 \\
\hline
\end{tabular}

Source: VHLSS1998-2014, income is in nominal terms.

Table 7: Mean Hourly Income Relative to Non-education Group (By Education Level for Whole Subsample)

\begin{tabular}{ccccccc}
\hline Year & No Education & Primary & Lower Second & Upper Second & Vocational & University \\
\hline 1998 & 1.0 & 1.0 & 1.2 & 2.5 & 3.0 & 8.0 \\
2002 & 1.0 & 1.3 & 1.2 & 1.5 & 5.6 & 10.1 \\
2004 & 1.0 & 1.1 & 1.1 & 1.7 & 2.1 & 3.4 \\
2006 & 1.0 & 1.1 & 1.1 & 1.6 & 2.1 & 3.6 \\
2008 & 1.0 & 0.8 & 0.8 & 1.1 & 1.3 & 2.5 \\
2010 & 1.0 & 1.0 & 1.1 & 1.2 & 1.6 & 2.8 \\
2012 & 1.0 & 1.1 & 1.2 & 1.4 & 1.7 & 2.6 \\
2014 & 1.0 & 1.1 & 1.2 & 1.4 & 1.6 & 2.4 \\
\hline
\end{tabular}

Source: Calculation from Table 6.

The common trend found here is that higher education's reward is lowering in relative terms for the whole sample. For the wage earner subsample, the gaps between hourly income of higher education groups and non-education group have been also narrowed in all educational groups but the decline has been the largest for university and vocational than lower educational groups. 
All these outcomes together imply that the expanded supply of higher graduated workers in recent years and/or more job mismatching jobs for higher graduated workers may explain the declining returns of higher education and then lowering the overall returns to schooling in Vietnam. Evidence from Tables 8 and 9 show this downward trend in the returns to post-high school education levels. Except for the two GFC years of 1998 and 2008, the returns to vocational and university level in relation to the none-education group have been declining since early 2000s.

Table 8: Returns to Schooling by Educational Level 1998-2014, OLS Estimates

\begin{tabular}{|c|c|c|c|c|c|c|c|c|}
\hline Edu level & 1998 & 2002 & 2004 & 2006 & 2008 & 2010 & 2012 & 2014 \\
\hline \multirow[t]{2}{*}{ Primary } & $0.109+$ & $0.1541 * *$ & 0.1209 & 0.0319 & $-0.3367 * *$ & $0.0900 * *$ & $0.1808 * *$ & $0.1432 * *$ \\
\hline & $(0.0653)$ & $(0.0361)$ & $(0.0891)$ & $(0.0850)$ & $(0.1152)$ & $(0.0312)$ & $(0.0260)$ & $(0.0257)$ \\
\hline \multirow[t]{2}{*}{ Lower second } & 0.045 & $0.2345 * *$ & 0.0596 & 0.0334 & $-0.2990 * *$ & $0.1151^{* *}$ & $0.2540 * *$ & $0.2262 * *$ \\
\hline & $(0.0644)$ & $(0.0347)$ & $(0.0894)$ & $(0.0852)$ & $(0.1151)$ & $(0.0310)$ & $(0.0274)$ & $(0.0259)$ \\
\hline \multirow[t]{2}{*}{ Upper second } & $0.305 * *$ & $0.5808 * *$ & $0.4949 * *$ & $0.3639 * *$ & 0.0034 & $0.2634 * *$ & $0.4233 * *$ & $0.4452 * *$ \\
\hline & $(0.0689)$ & $(0.0375)$ & $(0.0926)$ & $(0.0879)$ & $(0.1173)$ & $(0.0371)$ & $(0.0325)$ & $(0.0312)$ \\
\hline \multirow[t]{2}{*}{ Voc } & $0.251 * *$ & $1.0177 * *$ & $0.7888 * *$ & $0.7172 * *$ & $0.2933^{*}$ & $0.6258 * *$ & $0.6501 * *$ & $0.5850 * *$ \\
\hline & $(0.0879)$ & $(0.0415)$ & $(0.0913)$ & $(0.0870)$ & $(0.1162)$ & $(0.0379)$ & $(0.0510)$ & $(0.0307)$ \\
\hline \multirow[t]{2}{*}{ Univ } & $0.857 * *$ & $1.4153 * *$ & $1.3398 * *$ & $1.3179 * *$ & $0.9783 * *$ & $1.2225 * *$ & $1.1636 * *$ & $1.0069 * *$ \\
\hline & (0.0797) & $(0.0452)$ & $(0.0948)$ & $(0.0900)$ & $(0.1186)$ & $(0.0485)$ & $(0.0696)$ & $(0.0324)$ \\
\hline \multirow[t]{2}{*}{ Exp } & $0.017 * *$ & $0.0230 * *$ & $0.0362 * *$ & $0.0348 * *$ & $0.0448 * *$ & $0.0521 * *$ & $0.0555 * *$ & $0.0500 * *$ \\
\hline & $(0.0051)$ & $(0.0026)$ & $(0.0036)$ & $(0.0032)$ & $(0.0034)$ & $(0.0035)$ & $(0.0047)$ & $(0.0024)$ \\
\hline \multirow[t]{2}{*}{ Exp2 } & $-0.0007 * *$ & $-0.0006^{* * *}$ & $-0.0008 * *$ & $-0.0008 * *$ & $-0.0011 * *$ & $-0.0012 * *$ & $-0.0012 * *$ & $-0.0011^{* *}$ \\
\hline & $(0.0001)$ & $(0.0001)$ & $(0.0001)$ & $(0.0001)$ & $(0.0001)$ & $(0.0001)$ & $(0.0001)$ & $(0.0001)$ \\
\hline \multirow[t]{2}{*}{ Sex } & $0.2427 * *$ & $0.2177 * *$ & $0.1702 * *$ & $0.1735^{* * *}$ & $0.2408 * *$ & $0.2480 * *$ & $0.2340 * *$ & $0.1510 * *$ \\
\hline & $(0.0338)$ & $(0.0164)$ & $(0.0218)$ & (0.0189) & $(0.0196)$ & $(0.0200)$ & $(0.0190)$ & $(0.0144)$ \\
\hline \multirow[t]{2}{*}{ Constant } & -0.0575 & $0.2129 * *$ & $0.4092 * *$ & $0.7661 * *$ & $1.3892 * *$ & $1.3704 * *$ & $1.6398 * *$ & $2.0798 * *$ \\
\hline & (0.0959) & $(0.0495)$ & (0.1007) & $(0.0955)$ & $(0.1242)$ & $(0.0707)$ & $(0.1185)$ & $(0.0460)$ \\
\hline Prob $>$ F & 0.0000 & 0.0000 & 0.0000 & 0.0000 & 0.0000 & 0.0000 & 0.0000 & 0.0000 \\
\hline Observations & 3,244 & 26,268 & 7,177 & 7,436 & 7,532 & 7,166 & 7,758 & 7,868 \\
\hline
\end{tabular}

Notes:

Robust standard errors in parentheses, corrected for sampling weights.

+ significant at $10 \%$

* significant at 5\%

** significant at $1 \%$

The reference group is non-education. 
The returns to education level - the reference group is no education - and the returns to an additional year of schooling using the Heckman maximum likelihood estimator are shown in Figure 2. If we remove two special years which were affected by the two GFCs (1998 and 2008), the visualization of the trend for returns to post-high school levels or higher education have been falling since the early 2000s (see the bar chart in Figure 2). The average rate of returns to an additional year of schooling increased to 2008 then declined gradually thereafter (the line graph, RHS axis).

Table 9: Heckman Selection Model

1998-2014, Maximum Likelihood Estimates for Educational Level

\begin{tabular}{|c|c|c|c|c|c|c|c|c|}
\hline & 1998 & 2002 & 2004 & 2006 & 2008 & 2010 & 2012 & 2014 \\
\hline \multirow[t]{2}{*}{ Primary } & $0.109+$ & $0.1541 * *$ & 0.1209 & 0.0319 & $-0.3367 * *$ & $0.0900 * *$ & $0.1808 * *$ & $0.1432 * *$ \\
\hline & $(0.0653)$ & $(0.0361)$ & (0.0891) & $(0.0850)$ & (0.1152) & $(0.0312)$ & $(0.0260)$ & $(0.0257)$ \\
\hline \multirow[t]{2}{*}{ Lower second } & 0.045 & $0.2345^{* *}$ & 0.0596 & 0.0334 & $-0.2990 * *$ & $0.1151 * *$ & $0.2540 * *$ & $0.2262 * *$ \\
\hline & $(0.0644)$ & $(0.0347)$ & (0.0894) & $(0.0852)$ & $(0.1151)$ & $(0.0310)$ & $(0.0274)$ & $(0.0259)$ \\
\hline \multirow[t]{2}{*}{ Upper second } & $0.305 * *$ & $0.5808 * *$ & $0.4949 * *$ & $0.3639 * *$ & 0.0034 & $0.2634 * *$ & $0.4233 * *$ & $0.4452 * *$ \\
\hline & $(0.0689)$ & $(0.0375)$ & $(0.0926)$ & $(0.0879)$ & (0.1173) & $(0.0371)$ & $(0.0325)$ & $(0.0312)$ \\
\hline \multirow[t]{2}{*}{ Voc } & $0.251 * *$ & $1.0177 * *$ & $0.7888 * *$ & $0.7172 * *$ & $0.2933^{*}$ & $0.6258 * *$ & $0.6501 * *$ & $0.5850 * *$ \\
\hline & $(0.0879)$ & $(0.0415)$ & (0.0913) & $(0.0870)$ & $(0.1162)$ & $(0.0379)$ & $(0.0510)$ & $(0.0307)$ \\
\hline \multirow[t]{2}{*}{ Univ } & $0.857 * *$ & $1.4153 * *$ & $1.3398 * *$ & $1.3179 * *$ & $0.9783 * *$ & $1.2225 * *$ & $1.1636^{* *}$ & $1.0069 * *$ \\
\hline & (0.0797) & $(0.0452)$ & (0.0948) & $(0.0900)$ & (0.1186) & $(0.0485)$ & $(0.0696)$ & $(0.0324)$ \\
\hline \multirow[t]{2}{*}{ Exp } & $0.017 * *$ & $0.0230 * *$ & $0.0362 * *$ & $0.0348 * *$ & $0.0448 * *$ & $0.0521 * *$ & $0.0555^{* *}$ & $0.0500 * *$ \\
\hline & $(0.0051)$ & $(0.0026)$ & $(0.0036)$ & $(0.0032)$ & $(0.0034)$ & $(0.0035)$ & (0.0047) & (0.0024) \\
\hline \multirow[t]{2}{*}{ Exp2 } & $-0.0007 * *$ & $-0.0006 * *$ & $-0.0008 * *$ & $-0.0008^{* *}$ & $-0.0011 * *$ & $-0.0012 * *$ & $-0.0012 * *$ & $-0.0011 * *$ \\
\hline & $(0.0001)$ & $(0.0001)$ & $(0.0001)$ & $(0.0001)$ & $(0.0001)$ & $(0.0001)$ & $(0.0001)$ & $(0.0001)$ \\
\hline \multirow[t]{2}{*}{ Sex } & $0.2427 * *$ & $0.2177 * *$ & $0.1702 * *$ & $0.1735^{* *}$ & $0.2408 * *$ & $0.2480 * *$ & $0.2340 * *$ & $0.1510 * *$ \\
\hline & $(0.0338)$ & $(0.0164)$ & (0.0218) & (0.0189) & (0.0196) & $(0.0200)$ & $(0.0190)$ & $(0.0144)$ \\
\hline \multirow[t]{2}{*}{ Constant } & -0.0575 & $0.2129 * *$ & $0.4092 * *$ & $0.7661 * *$ & $1.3892 * *$ & $1.3704 * *$ & $1.6398 * *$ & $2.0798 * *$ \\
\hline & $(0.0959)$ & $(0.0495)$ & (0.1007) & $(0.0955)$ & $(0.1242)$ & (0.0707) & $(0.1185)$ & $(0.0460)$ \\
\hline Lambda & $\begin{array}{r}0.2529 * * \\
(0.0395)\end{array}$ & $\begin{array}{r}0.0832 * * \\
(0.0227)\end{array}$ & $\begin{array}{r}0.1613 * * \\
(0.0326)\end{array}$ & $\begin{array}{c}0.131 * * \\
(0.0283)\end{array}$ & $\begin{array}{r}0.1453 * * \\
(0.0340)\end{array}$ & $\begin{array}{r}0.2292 * * \\
(0.0403)\end{array}$ & $\begin{array}{r}0.1957 * * \\
(0.0569)\end{array}$ & $\begin{array}{r}0.0767 * * \\
(0.0188)\end{array}$ \\
\hline Obs & 20,627 & 80,750 & 20,866 & 21,209 & 21,311 & 21,630 & 31,150 & 30,721 \\
\hline Prob $>$ F & 0.0000 & 0.0000 & 0.0000 & 0.0000 & 0.0000 & 0.0000 & 0.0000 & 0.0000 \\
\hline
\end{tabular}

Notes
Robust standard errors in parentheses, corrected for sampling weights.

For briefness, we do not report selection equation estimates. The selection equation includes all variables in the wage equation, plus household size and household non-wage income. The reference group is non-education.

+ significant at $10 \%$

* significant at $5 \%$

** significant at $1 \%$. 
Figure 2: Changing Returns to Education 1998-2014

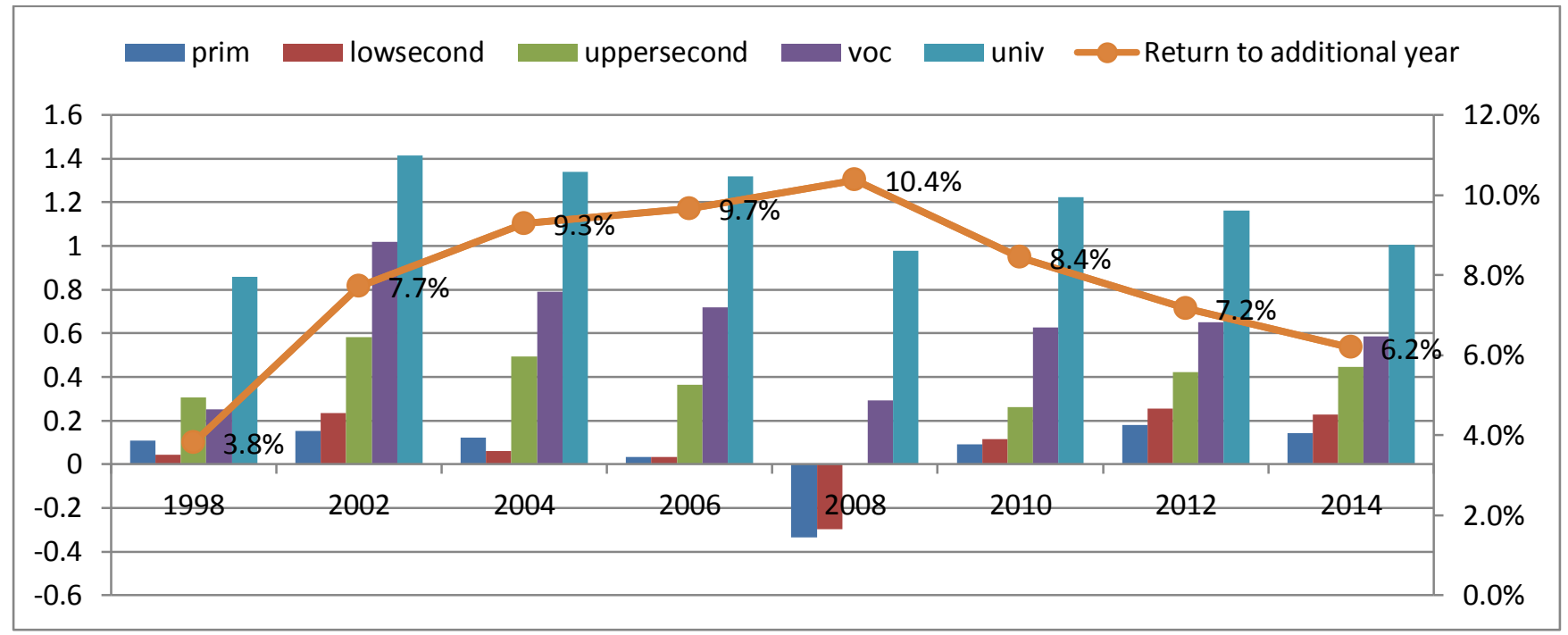

\section{Discussion and Conclusions}

In this paper, we report returns to schooling in Vietnam using updated and large scale nationally representative data of eight rounds of the Vietnam Household Living Standards Surveys of 1998, 2002, 2004, 2006, 2008, 2010, 2012 and 2014. The returns increased significantly during 1998 to 2008. The rise was much higher than estimates for period between 1992 and 1998 by Glewwe and Patrios (1998), Gallup (2002), and Moock, Patrinos and Venkataraman (2003). However, the returns appeared to fall from 2008 to 2014 using the latest data available. The falling returns seem to be robust to different model specifications and self-selection considerations, that is, self-selection into the wage labour market participation.

The rise of the returns during the 2000s was attributed to market opening and integration into the global economy such as accessing to the World Trade Organization (WTO) in 2006, deeper reforms, including introduction of Enterprise Law in late 1999 and a Unified Enterprise Law in 2005, and a consequent investment boom especially foreign direct investment (Doan and Gibson 2012).

However, the returns to significantly have declined since 2008, the decline seems to be larger than existing evidence for some Eastern European transition economies (Mysíková and Večerník 2014). The decline in the returns is more likely attributed to the expansion of education, particularly post-high school education, and a slowdown in economic growth after the GFC in 2008. As discussed earlier, higher education expanded rapidly by $144 \%$ during 2003-2011 resulting in an oversupply of higher-educated graduates, a higher unemployment rate amongst this group of workers, a lowering wage rates and then declining returns. Moreover, on the demand side, economic growth and economic transformation during this period (2008-2014) is significantly lower than prior to the GFC in 2008 except for the first GFC (1998-1999) period. Specifically, the economic growth rate on average was $8.8 \%$ for 
1992-1997, 5.3\% for $1998-1999,6.9 \%$ for $2000-2007$ but only $5.8 \%$ for $2008-2014 .^{6}$ A lower demand of higher skilled workers therefore may also explain the fall in the returns.

The returns in this paper are implicitly assumed to be not affected by unobservables (for example, individual ability and motivation) over time. It is assumed that the unobservables may affect the return in the same direction across years but they are constant over time. The trend of returns is then believed to be unchanged in the presence of endogeneity of schooling. Fixed effects modelling could address this issue. Unfortunately, we do not have a large overlapped proportion of the sample across surveys to set up a panel data for the fixed effects model. We believe, however, that our trend analysis follows common analytical practice in this field of the research.

The returns may be also driven by the quality of training and distortion in the labour market as we discussed. In future research we should examine returns by age cohorts, by type of schools, (that is, proxies for quality of training) and also examine how distortions affect the returns (for example, we could examine the relationship between returns to education and corruption or institutional indices across sectors and across geographic regions).

\section{References}

Becker, G. (1975). Human capital: A theoretical and empirical analysis with special reference to education, $2^{\text {nd }}$ edition. NBER, New York.

Booth, A, (2003) - Education and economic development in Southeast Asia: Myths and Realities. In Kwama Sundarman Jomo, eds. Southeast Asian Tigers? From miracle to debacle and beyond. London: Routledge Curzon.

Campos, N., and Jolliffe, D. (2003). After, before and during: Returns to education in Hungary (19861998). Economic Systems, 27(4), 377-390.

Christian, B. (2014). Skilling up Vietnam: Preparing the workforce for a modern market economy. The World Bank, Washington DC.

Colclough, C., Kingdon, G., and Patrinos, H. (2010). The changing pattern of wage returns to education and its implications. Development Policy Review, 28(6), 733-747.

Coxhead, I. and Phan, D. (2013). Princelings and Paupers? State employment and the distribution of human capital investments among households in Vietnam. Asian Development Review, 30(2) 26-48.

Doan, T., and Gibson, J. (2012). Returns to education in Vietnam during the recent transformation. International Journal of Education Economics and Development, 3(4), 314 - 329

Flabbi, L., Paternostro, S. and Tiongson, E. (2008). Returns to education in the economic transition: A systematic assessment using comparable data. Economics of Education Review, 27(2008) 724-740.

Fleisher, B., Sabirianova, K., and Wang, X. (2005). Returns to skills and the speed of reforms: Evidence from Central and Eastern Europe, China, and Russia. Journal of Comparative Economics, 33, 351-370.

Gallup, J. (2002). The wage labour market and inequality in Vietnam in the 1990s. World Bank Policy Research Working Paper No.2896. Retrieved 18 August 2012 from http://ssrn.com/abstract=636259

${ }^{6}$ http://data.worldbank.org/indicator/NY.GDP.MKTP.KD.ZG/countries/VN-4E-XN?display=default 
Glewwe, P., and Patrinos, H. (1998). The role of the private sector in education in Vietnam: Evidence from the Vietnam Living Standards Survey. Available at: http://elibrary.worldbank.org/doi/abs/10.1596/0-8213-4167-7

Heckman, J. (1979). Sample selection as a specification error. Econometrica, 47(1), 153-162.

Heckman, J., Lochner, L., and Todd, P. (2003). Fifty years of Mincer Earnings regressions. NBER Working Papers 9732.

IMF (2012). Article IV consultation. IMF country report No.12/165. Washington, DC: International Monetary Fund.

Katz, L., and Autor, D. (1999). Changes in wage structure and earnings inequality. In O Ashenfelter and D. Card, Eds. Handbook of Labour Economics, 3, 1463-1555, Elsevier Science.

Krugman, P. (1992). The age of diminished expectations: US economic policy in the 1980s, MIT Press, Cambridge MA.

Mincer, J. (1974). Schooling, experience and earnings. New York: NBER.

Moock, P., Patrinos, H., and Venkataraman, M. (2003). Education and earnings in a transition economy: the case of Vietnam. Economics of Education Review, 22(5), 503-510.

Munich, D., Svejnar, J., and Terrell, K. (2005). Returns to human capital under the communist wage grid and during the transition to a market economy. The Review of Economics and Statistics, 87(1), 100-123.

Mysíková, M., and Večerník, J. (2014): Returns to education in transition and advanced European countries: The role of an expansion of higher education. Trends and Challenges on Human Resource International Workshop. ISAG - European Business School, Porto, Portugal, 23-24 October 2014.

OECD (2003). Education Policy Analysis 2003, OECD, Paris.

Orazem, P., and Vodopivec, M. (1995). Winners and losers in transition: Returns to education, experience and gender in Slovenia. World Bank Economic Review, 9(2), 201-230.

Psacharopoulos, G. (1989). Time trends of the returns to education: Cross-national evidence. Economics of Education Review. 8(3), 225-231.

Psacharopoulos, G. (1994). Returns to investment in education: A global update further update. World Development, 22(9), 1325-1343.

Psacharopoulos, G., and Patrinos, H. (2004). Returns to investment in education: A further update. Education Economics, 12(2), 112-134.

Pscharopoulos, G., and Patrinos, H (2004). Returns to investment in education: A further update. Education Economics, 12(2), 110-134.

Rutkowski, J. (2007). From the shortage of jobs to the shortage of skilled workers: Labour market in the EU new member states. IZA Discussion Paper.

StataCorp. (2001). Stata User's Guide Release 7. College Station, Texas: Stata Press.

Večerník, J. (2013). The changing role of education in the distribution of earnings and household income. The Czech Republic, 1988-2009. Economics of Transition, 21(1), 111-133.

VHLSS. (1998, 2002, 2004, 2006, 2008, 2010, 2012, 2014). Vietnam Household Living Standards Survey: 1998, 2002, 2004, 2006, 2008, 2010, 2012 and 2014 [Datasets]. General Statistical Office (GSO), Hanoi, Vietnam.

Yang, D. (2004). Determinants of schooling returns during transition: evidence from Chinese cities. Virginia Polytechnic Institute and State University. 